This review has been accepted for publication in Metascience. The original publication can be found on link.springer.com.

\title{
A fascinating guide to creationist minds
}

Jason Rosenhouse: Among the creationists: Dispatches from the anti-evolutionist front line. New York: Oxford University Press, 2012, xiv+257pp, hardback, \$29.95.

\section{Stefaan Blancke ${ }^{1}$}

${ }^{1}$ The Moral Brain, Department of Philosophy and Moral Sciences, Ghent University, SintPietersnieuwstraat 49, 9000 Gent, Belgium, st.blancke@gmail.com

On a dark and cold December evening in 2008 a colleague and I were driving to a small town in Belgium to meet with two members of the creationist organization Creabel for an interview. I already had some idea of what the average creationist believes and, surely, to a large extent, the Belgian creationists confirmed the stereotype. However, what particularly struck me was their sincere concern with the fate of our souls if we were to continue to endorse evolution. This made me realize that to them, the question whether one accepts evolution or creation is not a matter of scientific fact, but in a very real sense, a matter of life and death. Although this experience was very illuminating, I have not pursued such encounters with creationists afterwards and have continued my research on creationism at a more abstract level. Jason Rosenhouse, however, is different. Being a mathematician, he has developed the unlikely habit of attending creationist conferences and visiting creationist museums. During these excursions, he not only repeatedly confronts the speakers with their mistaken conceptions, but also engages in lively and fascinating conversations with the individuals who populate their audiences. As he could not find the information he thus retrieved in the literature, he decided to write a book about his experiences. The resulting volume offers an original, intriguing and well-written introduction not only to the creationist mindset, but also to several scientific, philosophical and theological issues relating to the evolution/creation debates.

Indeed, the book, constructed around three conferences and a trip to the Kentucky Creation Museum, amounts to a lot more than an account of Rosenhouse's interactions with the creationists. That aspect alone nonetheless merits the attention of everyone who is interested in the phenomenon of creationism. As Rosenhouse explains, one of the key features of creationist culture is its insularity which safeguards its members from the allegedly degrading and even satanic impact of modern society. He also realizes, however, that the criticism of insularity can easily be hurled at any members of the academic world who so notoriously prefer to reside in their intellectual ivory tower rather than to go out and get their hands dirty. In order to avoid such insularity on his part, Rosenhouse decisively left the tower and met with real creationists. As he was so generous to share his experiences in writing, we can all break from our insularity with him. 
Rosenhouse intersperses his accounts of conversations he had with his fellow attendees with observations about typical creationist concerns, beliefs and practices, often with a personal touch. He explains why creationists do not always interpret the Bible literally and why they do not really believe that species are completely immutable; he points out the significance of conversion stories in creationist rhetoric, and condemns the unsavory creationist habit of quote mining; and he makes it abundantly clear that to creationists evolution means something radically different from the way scientists understand the term. By providing these and many other instances of creationist customs, Rosenhouse does not only allow his readers an intimate view into the psychology of particular individuals, but also offers them privileged access to characteristic, but often disregarded features of the creationist milieu in general.

To top things off, Rosenhouse frequently engages in succinct but thorough excursions on a range of related topics, including the problem of evil, the implications of evolutionary theory for religion, the notion of irreducible complexity and an evaluation of the various ways in which different types of fundamentalists interpret the book of Genesis. He thereby always manages to aptly summarize complex matters and nuanced debates in the space of a few pages, accurately describing the positions involved and precisely clarifying his own. As such, these sections not only constitute excellent introductions to these matters, but they also offer the reader much food for thought, inviting him or her to carefully consider and formulate one's own stance. Personally, I found little to quarrel with but I can imagine that others might disagree with several of the points and arguments he raises and it might not only be creationists or even religious people who take issue with him. For instance, recently a debate has emerged over whether the absence of the supernatural from scientific explanations, aka methodological naturalism, should be regarded as an inherent principle of science or as the contingent outcome of the scientific process. Elsewhere (Boudry, et al., 2010), my colleagues and I have argued for the latter position, which we dubbed Provisory Methodological Naturalism, and I was particularly happy to find Rosenhouse sharing our conviction. However, other non-believers who defend the teaching of evolutionary theory stand by the latter position, in large part because they are highly cautious about offending the religious sensitivities of some of their allies (e.g., Pennock, 1999). The rationale behind this strategy is that, if science cannot say anything about the supernatural in principle and if the supernatural hence lies outside the domain of science, then one can simultaneously accept evolutionary theory and believe in the supernatural. Propounded by the National Center for Science Education and the National Academy of the Sciences, this position has become quite popular. However, recently the number of voices questioning this view has increased considerably (e.g., Edis, 2002; Fales, 2009; Fishman, 2009). With Rosenhouse now joining their ranks, the debate continues.

As to the content, Rosenhouse's book deserves nothing but admiration. When it comes to the structure of the book, however, I am not completely convinced. The body of the text counts 219 pages, but it is divided in thirty-four chapters, with some chapters necessarily limited to a mere three to four pages, which is an unusual length. I cannot help but wonder whether the book would not have benefited from a more rigorous organization. Some of the chapters could have easily been merged into one, with each chapter dealing with a more general theme. On 
the other hand, one might rightly argue that the unique mix of personal experiences, astute observations and philosophical ruminations requires an equally unique structural approach. I leave it to the reader's predilections to decide which one he or she prefers.

Let me end by pointing out a phenomenon that understandably escaped Rosenhouse's attention: the relatively high number of European creationists presenting at these American conferences. The Creation Mega-Conference in 2005, for instance, hosted a Romanian geologist arguing that the evidence supports a young earth, a British zoologist claiming that accepting evolution leaves one without a purpose in life, and a German engineer delivering a confused talk about information. Their participation at these conferences offers yet another disconcerting signal that creationism is not, as Stephen J. Gould once described it, a "local, indigenous, American bizarrity", but has indeed spread around the world (Numbers, 2009).

To sum up, Rosenhouse has written a highly readable and captivating volume that provides us with an exceptionable perspective on creationism and the people who believe in it. Because of its original personal approach, the perceptive comments and the meticulous representations of intricate discussions, I warmly recommend Rosenhouse's With the creationists to everyone with even the slightest interest in creationism, fundamentalism, the relation between science and religion and the teaching of evolutionary biology. And to everyone else.

\section{References}

Boudry, M., Blancke, S., \& Braeckman, J. (2010). How Not to Attack Intelligent Design Creationism: Philosophical Misconceptions About Methodological Naturalism. Foundations of Science, 15(3), 227-244.

Edis, T. (2002). The ghost in the universe. God in light of modern science. Amherst: Prometheus Books.

Fales, E. (2009). Animadversions on Kitzmiller v. Dover: Correct ruling, flawed reasoning, from http://www.infidels.org/library/modern/evan_fales/intelligent-design.html

Fishman, Y. I. (2009). Can Science Test Supernatural Worldviews? Science \& Education, 18(6-7), 813-837.

Numbers, R. L. (2009). Myth 24. That creationism is a uniquely American phenomenon. In R. L. Numbers (Ed.), Galilei goes to jail and other myths about science and religion (pp. 215-223). Cambridge MA: Harvard University Press.

Pennock, R. T. (1999). Tower of Babel. The evidence against the new creationism. Cambridge: MIT Press. 